\title{
Lifeview and Perception of Message in Drama
}

\author{
P. C. JANSEN VAN RENSBURG
}

Dept. of Speech and Drama, P.U. for C.H.E.

ABSTRACT

The age-old controversy between church and the arts has not been resolved by a long shot. The ethically repellent in modern art is definitely over-emphasized at the cost of the ethically acceptable. This leads to the question about the Christian response to a play with a non-Christian lifeview, one in which the characters use crude language and in which vulgar actions are indulged in.

Before this problem is elucidated, certain terms are explained. This is then followed by a discussion of the general hermeneutic nature and method of the drama.

This is followed by a look at the role of prejudice in the process of dramatic dialectics and questioning. The perceptive playgoer will approach the play from the point of view of his own lifeview, but gradually he transfers to the point of view of the play. In this process his horizons are extended. Ultimately he has a wider vision than he would ordinarily have had. He does not miss anything or look over it - he just acquires a larger framework, with a more just proportion. The Christian therefore broadens his horizons through a continual trying of his prejudices against the rule of knowledge. In looking at the play En attendant Godot by Beckett, the Christian and the non-Christian come to an idiosyncratic message (after entering into play with the drama) on the basis of their idiosyncratic lifeviews.

What is to be rejected is any shaping approach based on pietism, reductionism and dogmatism. Ideally there should be a dialectical process at work in the witnessing of play wich will transcend the subjective conceptions of the play and of the playgoer. Then message perception in the drama will be a matter of more than the perception of the actual play in question - it becomes a oerception also of the message of life through the medium of drama.

One would have thought that after nearly nineteen centuries Christianity should have arrived at a generally acceptable point of view regarding the true status of the arts in a Christian community. If one looks, however, at the often vicious quarreling in our own day not only between Christian and non-Christian but often also between Christian and Christian, on matters pertaining to the religious nature, aim and methods of the arts, then it would seem as if the ageold controversy between church and the arts has not been resolved by a long shot.

Within the ranks of church and art in Western Christian society there are roughly two groups: on the one hand we find those who are strenuously opposed to any artistic expression of naked reality whatsoever, and who would even 


\section{Lifeview and Perception of Message}

denigrate this as "septic art". These individuais then over-react by almost naively striving to achieve "pure art" by idealistic means; on the other hand one finds those who find the idea of "pure" or "clean" art irresistibly funny and who then in turn over-react by an almost tauntingly direct expression in artistic terms of what is vicious and unprepossessing in life.

This situation - especially as it pertains to the South African society - has prompted me increasingly in the recent past to ask the following question: Why should these two parties oppose each other so resolutely and so directly? Would this be the result of a pathetic misapprehension of each other? It has often been suggested of the Afrikaner that he is more naturally inclined towards schism than submission. Are we not then in the stubborn holding to our own ideas often inclined to follow our own lead without leaving open the option that God's voice might be heard along with those of others?

The struggle between these two groups is strongly characterized by a denigration of the fact that both the good and the bad have a right to existence in the arts as long as certain esthetic and ethical norms are adhered to.

Especially as regards the ethical norms a work of art would, as far as $\mathbf{I}$ am concerned, be unacceptable from a Christian point of view should the ethicall repellent in it be presented as laudable.

It is also true wat the ethically reprellent in modern art is definitely overemphasized at the cost of the ethically acceptable. The fighters for "pure" or "clean" art do have right on their side if they feel that there is a need for the portrayal of the ethically good in contemporary art. But it is essential that in their struggle against the advocates of the ethically repellent in art they should come to some acceptable stand as regards the aim, nature and method of art as an esthetic portrayal of the ethical qualities of life. Before a mutual understanding of each other has been reached and before knowledge about the essential nature of the arts by both parties has been apprehended, the way to a truly Christian perception of culture will remain closed.

The ignorance of members of the public regarding the aim and the nature of art emerges most clearly when one has to do with the field of the performing arts. Most of us, for example, know how to handle the constructive didactic messages of the TV series, The Littie House on the Prairie. But when we come to a play in which the message is not so clear, or where the message is obscured 


\section{P. C. Jansen van Rensbury}

under an uncompromising portrayal of the mainly rough side of life, such as in Fugard's Hello and Goodbye then we land in very unnavigable waters.

$$
\text { it }
$$

A question which troubles many Christian drama-goers is the one about one's Christian response to a play with a non-Christian lifeview, one in which the characters use crude language and in which vulgar actions are indulged in An individual's perception of a play, of the message of the play, of necessity involves his personal lifeview. And this is where the problem rears its head.

Experience in the theatre has taught that the average theatre-goer is usually deficient in knowledge regarding the nature and the method of message perception as influenced by lifeview in the drama. Ignorance in this field has a limiting influence not only on the playgoer's perception of a play, but also on the general functioning and development of the drama.

Drama is esthetic communication of various intrinsic and extrinsic values. Without a proper perception of what is being communicated, there is of necessity malcommunication, misapprehension and even a clash between the com municating parties. Mostly the cause of unjustified drama censorship may be found exactly in malperception, which is based on the wrong attitude in culcated by lifeview in the receiver of the communicated message.

Ic is thus important for all the interested parties in the drama to come to some resolution about the matter of what message perception for the playgoer means and what part is played in this process by his personal lifeview and his private norizons.

This paper is a modest attempt to illuminate some aspects of the issue and to come to some sort of conclusion which might stimulate further thought on the issue at stake.

Before the main argument can be commenced, certain terms which will be used throughout should perhaps be elucidated. These terms might just be confusing. They are: Play, drama, scene, theatre, dramatic art ensemble, hermeneutics of drama and the message of the play.

By play I mean performed drama. The script (the play) is seen in this context as the scenario of the complete work of dramatic art. In this light the playwright represents only one of the members of the ensemble of dramatic art. 


\section{Lifeview an Perception of Message}

Scene ("toneel") means the fleeting, transient activity, the process uring which the ensemble and the playgoers together enjoy a play creatively as a group of inidividuals.

The term theatre refers to the place or the building where the play takes place.

I prefer to talk of the dramatic art ensemble rather than of dramatic artists, because drama is a complex art and no single member of the ensemble is in reality an artist in his own right. All of them together fulfil the role of an artist and for that reason the stress is on the term dramatic art ensemble.

Hermeneutics of drama to me implies the perception of the message of the play. Perception, in the sense in which I use the term, means to perceive with one's whole being (that is, intellect, will and emotion), to understand and to interpret. It is at once cognitive and normative. The term bermeneutics was derived from the proper name of Hermes, the antique Greek mythological messenger and interpreter of divine messages.

Drama is formative in the sense that it is communicative of principle, of the foundational. Each play has an ultimate overarching message which has to be communicated to the playgoer. This message may be didactic and/or investigative and formative in essence. The message of a morality play, for example, is usually didactic and formative in nature. A play which looks at the sense of life only to ask questions in turn carries an investigative-formative message. The fact that the latter may prompt the playgoer to formative self-investigation might render its message more strongly formative than is the case with the outright morality.

Because it is the play which directly addresses the playgoer and which then communicates itself, I prefer to refer to message of the play and not to the message of the dramatic art ensemble. The judicious playgoer does not, in the course of the production, ask about the meaning of the ensemble but about the meaning of the play. He also does not question the lifeview of the ensemble but rather the lifeview as expressed in the play. I stress in particular the fact that the lifeview of the play is given shape through its message as portrayed in its totality of iorm and content. It is a dangerous misconception to assume that the expression of the lifeview of a play is of necessity contained in the view and in the actions of one or more of the characters in a play. More will 


\section{P. C. Jansen van Rensburg}

be said on this later. For the moment it is enough to note that the messageperceiving playgoer should be aware of the complete content as well as the form of a play.

Beckett's En Attendant Godot (1952) and Dürrenmatt's Play Strindberg (1971) are perhaps the clearest examples of plays where the message of the play is contained also in the structure of the play. The nearly identical structure of the two acts of the former play would seem to suggest with the content of the play that life is an absurd cycle of unchangeable conditions and events for those who blindly and therefore fruitlessly wait for happiness. The highly dramatic structure of Play Strindberg is an even clearer example. Here the content of the play gains the meaningful and stimulating shape of a boxing contest complete with strokes of the gong and the announcement of the rounds. The theme of the play is marriage.

In order then to investigate the nature and the method of the playgoer's message perception as coloured by his lifeview, a discussion of the general bermeneutic nature and meibod of the drama is essential.

\section{THE GENERAL HERMENEUTIC NATURE OF DRAMA}

Drama is a transient form of art which demands direct perception. In a certain sense this may be compared with a game and a conversation.

Each performance of a play is a fleeting, trancient work of art, which takes place under idiosyncratic conditions and which is the result of fresh creative impulses and perceptions even though these are fundamentally based on a fixed text and mises-en-scène. A production cannot be stored as a work of art in any real way. It is a singular event. This means that the playgoer will have no true record on the basis of which he can later base an intensive retrospective analysis and evaluation of the play.

Not even the text of the play or the director's notebook is a complete record of the performance - these could only be records of certain important constituent parts of the total work of art. For this reason effective message perception for the playgoer is based on a direct perception of the play as it unfolds in front of him.

The playgoer also cannot, as the reader of a text could, pause for an unspecified time and reread a specific part with the intention of subjecting that part to 


\section{Lifeview and Perception of Message}

intensive study. The play runs in acts and it is only during the interval between acts that the playgoer has the opportunity to think retrospectively in any way of the contents of the play.

On the basis of this essential characteristic of drama some people have maintained that drama limits true message perception, and for this reason they turn to literary analysis and evaluation of drama. As we have already noted, however, the true message of the play is locked also in the living performance of the play, those people would inevitably encounter an even more limited perception of the message than the one they are trying to evade.

It is also true that a direct perception of the message is preferable to a merely retrospective one, especially in view of the fact that the latter leaves more room for deliberate percpetion. In reality it is preferable for the playgoer to be exposed to the clues of meaning as they unfold on the stage and for him gradually to construct an image on the basis of these perceived impressions. At the end he will then have a fixed image on which to base his spesific interpretation of the message cognitively and normatively.

Another important essential characteristic of drama which results from the above and which might be linked with the transient nature of the play is its continual presentness. In drama imaginary and artistically convincing human action is represented as an immediately audible and/or visible continual presentness intended for direct sense perception.

The result of this important distinguishing characteristic of the play is that in drama the playgoer has a continual sense of expectation and interest in future implications of present actions. Because he feels, as it were, involved in the presentness of the action he waits in suspense for what is to happen next.

Dramatic activity takes place within a spesific continually developing presentness of time and space. Because the form of the play consists of this aspect, there is in the course of the performance also a sense of expectation as regards the end of the play. For that reason the structure of the play as such is not important for the playgoer, for only the expectation of the completion of this structure has real importance. As long as the performance is under way there is no such thing in drama as completed form. The sense of completion can only be experienced retrospectively and in the memory. The influence 


\section{P. C. Jansen van Rensburg}

of the structure of a play does not lie in its completeness, however, but in its suspended in completeness during the performance.

The playgoer usually predicts and expects certain actions rooted in time and space and in the process of the completion of what he has experienced in conjunction with the characters in the play he is either disappointed or satisfied. He shares in the resulting joy or heartbreak of the characters and so gradually discovers the overarhing message of the play. In this way the playgoer waits with Vladmir and Estragon (in Waiting for Godot) for the coming of Godot and thus also for the ultimate completion of the form. At the end of each act the playgoer is disappointed anew by the development of what happens in time and space. Every time the playgoer realizes that his anticipations have been erroneous, and gradually the playgoer detects in the course of the play a wild cyclical structure of seemingly identical events rooted in time and space, repeating themselves endlessly. The fruitless anticipation of Godot's coming and the resultant absurd completion of the form (the cyclical form) have an upsetting influence on the playgoer. He is bothered by Godot's tardiness. He is stimulated to decide for himself whether life is really so meaningless. He has to decide who Godot is, and why this fruitless waiting is necessary. The play has thus succeeded in communicating its investigative-formative message effectively.

In effect it would seem as if there is a sort of conversation in drama between play and playgoer about the expected resolution of the continually present action in time and space as well as the meaning and the value of this action. One could perhaps say that the drama is like a game and a conversation in which two parties are involved - the playgoer on the one hand and play on the other hand.

Should we liken the play to a game, then we could say that the playgoer and the play represent two players within whom the game (drama) should fulfil itself. With game I do not mean game, set or match, but playing as such, drama, not the play.

Any game is associated with the movement to and fro of the participating players. This lasts for as long as the movement lasts, and it retains life for as long as the movement remains vital and dynamic. The perpetual lasting of the game rests on the fact that there is no final aim which the players can attain. When victory in tournament is not in itself an aim, then the players will tackle each other again. In competing with each other then they try in reality to 


\section{Lifeview and Perception of Message}

attain victory over the game itself. But the fact that the game always strives tc master the players sees to it that the final aim remains in the background and that the game retains life. The resultant endless structure of the game involves the players to such an extent that they have a spontaneous inclination to a continual repetition of the game and the patterns of movement which develop within the game.

For this reason Gadamer $(1975,96)$ has said that "all playing is a being-played". It is precisely this characteristic that drama has in common with a game which contributes to the fact that drama always leaves room for continually developing perceptions and interpretations of life.

In drama the play and the playgoer both play with a particular idea or issue and each comes to a particular conclusion - a conclusion which offers new challenges for the continuation of the game, even though this conclusion might not be an end in itself. Even in the case where the conclusion arrived at by the play constitutes a didactic reply to a certain issue, there might still be enough of a challeng left to continue the game, on condition that the playgoer does not accept the conclusion arrived at by the play totally uncritically.

Any game poses a specific kind of challenge to the players. The enjoyment (or the entertainment) of the games lies in the fact that the players play themselves out in the acceptance of the chatlenge and in its execution. Drama faces the play and the playgoer with the challenge of trying to understand life, or to be more explicit, to attempt to plumb human emotion and to try to find solutions for issues surrounding this. As in any game, the enjoyment or the entertainment, the satisfaction, is to be found in the extent to which the drama offers the participating parties the opportunity to play themselves out in the order and the shape of the "game". It is not to be found in the realization of the ideal to which everyone has been challenged, but that is, not in finding correct, valid-for-all-times answers to particular issues, but in the ordered and shaping playing with various possibilities and coming to each most probable conclusion in this respect. This conclusion would ultimately be an embodiment of the lifeview of each participant - a playing out of the self. A player in any game plays himself, represents himself, exhibits his knowledge, abilities, attitude and nature. In the same way the playgoer and the play reveal their idiosyncratic separate attitudes as inculcated in their lifeviews - and these are weighed against each other as in an argument. 


\section{P. C. Janswn van Rensburg}

One should theretore compare drama in a certain sense with a conversation between two parties in which both participants try to evaluate the manner of expression of the other continually through continual questioning and testing.

In any logical and penetrating conversation or argument the participants continually question each other about the subject with which they are dealing cognitively and normatively in the course of the conversation. A facet of any aspect that one party might concede to know little about is brought out into the open by setting a question about it to the other party. This would be a question for which there is as yet no answer, so that thought will be stimulated through it. The other party responds to the question by asking a further question in the same direction.

In this way, for example, the playgoer plumbs the message of the play and the foundational underlay of the play by delimiting the open question of which the play seeks to be the open answer. In his effort to delimit this, the playgoer himself sets an open question about life as the play presents it to him. The process of inquiring about the nature of the question posed by the play is, however, part of the process of being asked oneself - "playing is being played".

This questioning, of course, takes plac within the thought processes of the audience itself. In classical Greek drama the traditional chorus, however, in a sense represented the audience, or guided the audience by continually setting questions to the play and the players out loud - these questions were then responded to by the action of the play itself.

A last remark regarding the hermeneutic nature of the drama in comparison with a conversation:

In order to come to some sort of conversational contract with somebody or rather to determine his point of view, implies the inclusion of his mental horizon within the scope of my own: the inclusion of his attitude within my own field of comprehension. Total self-expression and successful maintenance of one's own point of view is the death-blow of any form of hermeneutics.

One cannot, however, compare a play in all respects to a conversation as it occurs between two people. The play itself does not talk - the playgoer induces it to talk through questioning. And now one is faced with the danger that the playgoer might well force the play to talk as he does, to induce it 
to represent his own horizons and his own viewpoints. But the fact that the question posed by the playgoer which sets the play talking has to derive directly from the answer locked up in the play more or less reduces this danger.

\section{THE GENERAL HERMENEUTIC METHOD OF DRAMA}

One could typify the hermeneutic method by means of which the playgoer perceives the message of a play as a dialectical process dependent on receptive perception.

Dialectics implies the art of divining the truth of concepts and to test these by means of discussion and logical debate.

The dialectics of dramatic hermeneutics were already touched upon in the previous paragraph where it was maintained that the playgoer and the play are involved in a reciprocal debate or discussion through reciprocal questioning - with the aim of ultimately arriving at each other's open conclusion.

The receptiveness of the playgoer towards the meaningful content and the form of a play as against his lifeview and foundational prejudices are of cardinal importance in this method of dialectical questioning with a view to perception of the message. For this reason it is essential that one should look at receptive perception and the role of bias or prejudice more closely.

When one maintains that the playgoer has to be receptive to the content and the form of a play, one means that he should have a balanced receptiveness for the form and content of the play. I say balanced receptiveness and mean by that that his receptiveness should not be over-active but by no means underactive either. The playgoer with the over-active receptiveness is the one who compulsively seeks to collect impressions without savouring the delight of dwelling on the meaning and the form of these same impressions. Usually his perception of the message is limited. Under-active receptive perception is a characteristic of the compulsive social playgoer as well as of the unilaterally evaluating playgoer. The former regards drama usually as a purely social occasion. His perception of the drama is normally limited. He is under-receptive for all problems and issues in the play which might force him to think and tends to ignore them because they might inhibit his social relations. The compulsive unilaterally evaluative playgoer on the other hand is the one who is not perceptively sensitive to the play as a whole but only for isolated aspects of 


\section{P. C. Jansen van Rensburg}

the play. He is the one who would separate the ethical aspects of the actions of the characters from the intrinsic and other extrinsic values, try to perceive these outside the total structure of the play and then express an opinion on the play based on these fragments. Keeping to a fixed preconceived opinion about a play is usually a characteristic of his dialectical dealings with the play. He usually regards differences of opinion as obstacles which have to be removed and cannot regard these as challenges to his ability for dialectical reflection.

Dialectical receptive perception in drama is further characterized by its reciprocal nature. Drama involves a complex interaction between play and playgoer in which both as it were exchanges ideas as regards the nucleus of truth underlying their discussion. Drama is totally different from a one-way transmission or a one-way perception of indubitable facts of life. Therefore the playgoer's perception of the message should not be regarded as an objective and intellectual plumbing of certain already determined and canonical layers of meaning in a play or of the original intention of the ensemble with the play. We have already pointed out that the playgoer ought to ask what the play has to say to bim here and now, and which horizons are opened up to him in his association with the play. In the process of receptive perception the playgoer enters into a reciprocal conversational situation with the play and he questions the message of the play and the truths behind the conversation he has entered into through the perceptible meanings that these might have for his own present life.

It is misleading in drama to distinguish between the subjectivity of the interpreter and the objectivity of the interpreted material, or to regard the playgoer as subject and the play as object, because in the process of receptive perception the process of knowing is in reality also the process of being known. For that reason it is essential that the playgoer should open up to the demands of the play, should be willing to play along, should play himself out and ultimately to be played himself.

In fact, drama for the playgoer means receptive perceptive responding involvement. This is involvement in the sense that he is gripped as a complete man, brain, will and emotion, and drawn into the play, stimulated to response by the illusionistic events on the stage. In this process of involvement he is as it were "played" by the play. He forgets himself in the process and also forgets his presentness, his everyday life and real circumstances. But because he can never escape his idiosyncratic being the process eventually culminates in the 


\section{Lifeview and Perception of Messags}

fact that he discovers himself within the wider context of human existence. Gadamer (1975) states it in the following terms: " . . . to the ecstatic self-forgetfulness of the spectator there corresponds his continuity with himself. Precisely that in which he loses himself as a spectator requires his own continuity. It is the truth or his own world, the religious and moral world in which he lives which presents itself to him and in which he recognises himself .. The absolute moment in which a spectator stands is at once self-forgetfulness and reconciliation with self. That which detaches him from everything also gives him back the whole of his being" (p. 113).

This aspect of the self-discovery in drama is closely linked with the fact that the playgoer recognises himself and his own finiteness in the lot of the characters on the stage. His recognition of life as it is or at least as the play says that it is must of necessity be founded on his measure of self-knowledge. "The spectator does not hold himself aloof at a distance of aesthetic consciousness enjoying the art of representation, but in the communion of being present", Gadamer (1975, p. 117) states. With reference to tragedy he notes that "the real emphasis of the tragic phenomenon lies ultimately on what is represented and recognised and to share in it is not a question of choice. However much the tragic play that ia performed solemnly in the theatre represents an exceptional situation in the life of everyone, it is not an experience of an adventure producing a temporary intoxication from which one re-awakens to one's true being, but the emotion that seizes the spectator deepens in fact his continuity with himself. The tragic emotion flows from the self-knowledge that the spectator acquires. He finds himself in the tragic action, because it is his own world, familiar to him from religious or bistorical tradition that be encounters .... (my italics).

The italicized part points to Gadamer presupposing a certain knowledge of life in the playgoer, a knowledge on the basis of which he can recognise the truth in the play and on the basis of which he can recognise himself in the course of the process during which he is being known. This knowledge is inextricably linked to a lifeview on the basis of which he can interpret, apply and evaluate the message of the play as it applies to himself.

This knowledge usually consists of certain untested parts as well as tested parts and prejudices proved to be true. When a playgoer approaches a play with knowledge of life based mostly on untested prejudices, it is improbable that his perception, especially as regards self-discovery, would be receptive. 


\section{P. C. Jansen van Rensburg}

Let us, however, look more closely at the role of prejudice in the process of dramatic dialectics and questioning.

\section{ROLE OF PREJUDICE}

All perception inevitably involves prejudice or bias - prejudice based on the content and the structure of the perceived object. This is also true of the playgoer as regards perception of the message. These prejudices can be justified or unjustified.

His receptivity to the usual clues of meaning in the play and his willingness to strive after new horizons will help him to discover the degree of correctness or justification of his prejudices.

The perceptive playgoer usually approaches the play from the point of view of his own lifeview, but gradually he transfers to the point of view of the play. In this way his horizons are extended. In the process of his viewpoint shifting to include that of the play his own horizon is extended. Ultimately the playgoer has a wider vision than he would ordinarily have had. He does not miss anything or look right over it - he sees better, within a larger framework or in more just proportion.

One could compare this with two individuals ( $\mathrm{X}$ and $\mathrm{Y}$ ) who look at their horizons (constructed, say, of mountain peaks) from differing points of view:

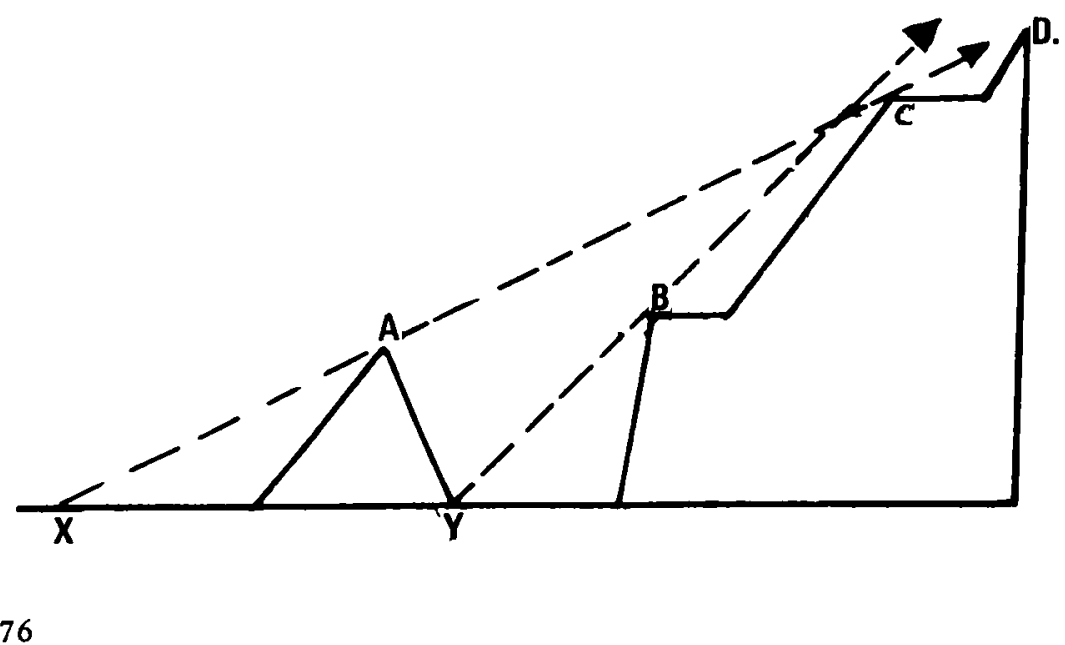


For $\mathrm{X}$ the horizon is created by $\mathrm{AC}$, and because he cannot, from point $\mathrm{X}$, determine the distance between $\mathrm{A}$ and $\mathrm{C}$, it seems to him as if his horizon consists of two peaks. He does not even see the peak which constitutes the horizon perceived by $Y(B)$. Y, on the other hand, does not necessarily from his viewpoint see the peak which for $X$ constitutes the $C$-part of his horizon. Should $X$ move to $\mathrm{Y}$, his horizon will change not only from $\mathrm{AC}$ to $\mathrm{B}$, and he will not only discover that $\mathrm{AC}$ is constituted of two peaks belonging to two different mountains, but from the knowledge gleaned from his old perspective $(X)$ he will also know what $Y$ does not know, and that is that behind $B, C$ is still to be found.

He bias or prejdice towards $\mathrm{AC}$ would thus seem to have been justified (through his move away from $\mathrm{X}$ to $\mathrm{Y}$ ) on the one hand, while unjustified on the other hand. In this way his horizon was extended and his bias exposed to testing. On the basis of his justified prejuduces (but, note well, not on the basis of his untried prejudices from viewpoint $X$ ) he could then conclude that the horizon as seem from $Y$ would well be $B$, but that if one should see $B$ in more just proportion and with in the framework of the larger whole (as part of a chain of mountain peaks) even though it would not seem so from the first viewpoint. But this conclusion then also rests necessarily on certain untried prejudices again. From viewpoint $\mathrm{Y}$ he could on the basis of untried prejudices as well as through his tried knowledge conclude that $\mathrm{B}$ and $\mathrm{C}$ could possibly consist of two mountain peaks. Only when $B$ and $C$ become his new viewpoints will he be able to approach the truth more closely, which is that horizons $B$ and $C$ consist of plateaux and not of peaks. From viewpoint $B$ he does not yet know of horizon $\mathrm{D}$ and he does not yet know of anything behind $\mathrm{D}$. It is only when, shifting gradually from $\mathrm{Y}$ to $\mathrm{B}$ to $\mathrm{C}$ and to $\mathrm{D}$ that he will gradually uncover a fuller truth. Then only can he look back and see that his previous horizons have become amalgamated and that he can now see and evaluate everything within a larger whole.

In this way the Christian also moves in his daily life from viewpoint to viewpoint (according to the Calvinist reformatory tradition) and he broadens his horizons through a continual trying of his prejudices against the rule of knowledge dicovered to be true as this is revealed in the Scriptures and in his contact with life.

Whover remains stuck at point $X$, therefore limits his lifeview (a Christianoriented one) to horizon $\mathrm{AC}$ and then regards his untried prejudices as final 


\section{P. C. Jansen van Rensburg}

unmoveable opinions and criteria on the basis of which he derogates all other conclusions based on lifeview as false and dangerous, is in danger not only of falling into pietism, but he also creates the impression that Christianity is guilty of an ill-judged and blind lifeview.

Should a particular play carry an agnostic message (therefore, from point $\mathrm{Y}$ represent life within the narrow horizon provided by $B$ and then portray human suffering as the product of circumstances which can only be altered by man himself, seeing that God does not involve Himself with man and his suffering - as one could say Athol Fugard does in Hello and Goodbye), then the receiving playgoer of Christian conviction will allow himself to be carried along from, say, point $X$ to point $Y$ and gradually and ultimately retrospectively he will test the prejudice of bias contained in the play against the knowledge within himself which has been proved true. This will enable him to conclude that the horizon does extend beyond B. God does involve Himself with man in his suffering. The whole issue of suffering is not accurately portrayed when viewed from point $Y$. Man does not aggravate his suffering because he suffers from a "God complex" as Y would seem to conclude, but because he has an erroneous concept of God because he thinks of God as a jealous and punishing destroyer of freedom.

The Christian playgoer and the agnostic play therefore "play" dialectically with a particular aspect of suffering and the possible answers. Ultimately the Christian playgoer comes to a plumbing of the message (the conclusion) of the play and he also comes to personal conviction regarding the truth and the value of this message and regarding the meaningfulness and the value of the "game/ discussion" as such. The shaping joy that he experienced does not mean that he came to any final conclusion but that in his contact with the play (even though he does not fully agree with the lifeview expressed in it) his personal horizons were extended and he has learned enough from this to be able to see human suffering in more just proportion than before.

The fact that he was led to eventual self-discovery as well as to a discovery of his perhaps unfounded prejudices regarding the meaning of human suffering contributes to his having been able to receive not only a purely Christian perception of the message of Hello and Goodbye but also that he was able to gain an idiosyncratic meaning and value from the relevant "game/discussion" as such.

When the message of the play, for example, has a strong dogmatic/didactic underlay, then the idiosyncratic character of the playgoer's perception emanating 


\section{Lifeview and Perception of Message}

from his lifeview is more clearly visible. A Catholic, for example, will gain other truth and values from the Medieval Miracle Play Mariken van Nijmegen than a Protestant, because a Protestant's view of penance is different from that of a Catholic. They would most probably agree as to the theme of the play, but they differ as to the truth and value of the lifeview expressed in the play. When one comes to a fairly universal message in a play such as Beckett's En Attendant Godot it could easily happen that the Christian will find enough Christian truths in the play to typify it as having a Christian message, while the existentialist will in turn find enought existentialist truths and values in it to claim it for himself with equal justice.

In this play by Beckett two pathetic souls wait for the coming of a certain Godot who has promised to meet them there on that day. It is clear that they have been waiting for quite some time. While they are waiting, paralysed with boredom (at times impatient, at times bereft of all hope) they play games to while away the time. Suddenly a pompous type, Pozzo, appears with his slave Lucky. Lucky is bowed under the weight of his master's possessions and is driven on by a long whip carried by the master. Vladimir and Estragon, the two hoboes, find Lucky an interesting curiosity and they find joy in his presence. When Lucky ultimately begins to talk after his master's prodding, he sounds like a defective computer. His thoughts make no sense. They do not understand him but they still find him interesting. Later they begin to protest against it and they violently silence him. After Pozzo has left again with his slave, the boredom returns. At the end of the act a small boy arrives and tells them that Godot has promised to come the following day.

The second act plays the following day. The events are almost identical to the first day. Pozzo and Lucky appear again. And at the end of the act Godot sends another message that he will return the next day. One irresistibly gets the impression that the following day will inevitably follow the pattern of the preceding ones.

The play necessarily has an upsetting influence on the audience. The playgoer feels with the characters the terrible boredom and the impatience attendant on the fruitless waiting for the tardy Godot. The intellectual and the emotional responses of the audience, however, differ. Everyone will of necessity respond to the stimulating and mysterious issues surrounding Godot from his own viewpoint as shaped by his lifeview. 


\section{P. C. Jansen van Rensburg}

The existentialist would, on the basis of his dialectical contact with the play come to the conclusion that life is an absurd process of waiting for a dream image - that the meaning of existence is situated in the fact that one has to use up time with meaningless little games without expecting too much from the next moment.

The Christian on the other hand would be able to say at the end of the play that life is absurd and meaningless for those who wait blindly.

Godot keeps to his word. He comes every day, just as has promised. The fact, however, that he comes in the martyr's guise as Lucky and speaks a language that they do not understand, makes them miss the meaning of his coming. This inevitably inculcates in the Christian playgoer an awareness anew of the denigrated coming of the Messiah in the shape of an unimpressive servant.

The existentialist and the Christian both then come to an idiosyncratic message on the basis their idiosyncratic lifeviews after an investigative-shaping questioning process aimed at the play. Who is Godot? Why are they waiting for him so fruitlessly? Beckett himself felt that each and everyone had to find an answer to this for himself. It is said that when someone on occasion asked Beckett who Godot was, his reply had been that if he had ever known he had by then forgotten anyway.

\section{CONCLUSION}

Should I now have to come to some sort of conclusion regarding the role of lift view in drama on the basis of the hermeneutic nature and method of message perception, I would say the following:

The personal lifeview of the playgoer plays a conclusive role. When the playgoer's approach to a play (based on his lifeview) is pietistic, dogmatic or reductionist in nature, this role of lifeview is almost exclusively negative determinist therefore it does not only prevent tue pcrception, understanding and interpretation of the meaning and the overarching message of the play, but it also contributes to the fact that the playgoer develops a sense of antipathy towards the play. He therefore becomes inured to the truths behind the "conversation" as well as to the shaping values of the "conversation" as such.

A pietistic approach is one where the playgoer hesitates to land in a situation where his personal convictions based on lifeview are questioned and where 
he is challenged to an argument or a re-assessment of his views. As soon as there is a difference of opinion between himself and the play, he walks out, without giving the play an opportunity to state its entire message. This, of course, is only if he has not in the first place allowed hearsay sensationalism to prevent him from going to the theatre in the first place to save his tender susceptibilities from assault. This sort of puritan pietism is responsible for the death of true Calvinism. Calvin Seerveld $(9168$, p. 15) has observed that "Pietism's built-in hesitancy, distrust of cultural activity will never make a milieu congenial to the production of art". The pietistic playgoer is usually sceptical not only as regards the avant-garde in the extrinsic but also in the intrinsic qualities of dramatic art. Anything that is strange or unconventional seems to him to be a threat. Such an attitude to life, to my mind, cannot be reconciled with the command Christ gave, viz. that his followers should be the salt of the earth - not the acid which corrodes everything that is new without discrimination.

When a playgoer approaches the message and the value of the play in a reductionist sense as regard lifeview, then he reduces the aspect of lifeview to the lifeview of the characters of even of the ensemble. Thus it could happen that he regards the play as dangerous to lifeview as a whole, mainly on the basis of the actions and the words of the characters which might strike him as vulgar. Hello and Goodbye, according to him, would then not be suitable to be played in a Christian community, because Hester has an atheitic view of life and she takes the name of God in vain. His reductionist approach would then blind him to the message of the play in its entirety, viz. that an erroneous concept of God limits man's full realization of his total potential.

The dogmatic approacb is characterized by a tendency to maintain under all circumstances one's personal bias, whether tried or untried, as dogmatic principle or opinion. One finds this approach especially in the playgoer who makes it his purpose to argue his dialectical conversational companion, the play itself, to death. He also tends to regard his own conclusion regarding the message of the play as final and unshakeable, even though it might be untested. This type of approach compromises the dialectical nature of drama. Dialectics does not consist in trying to pounce on the weakness of what your conversational companion might be saying (Gadamer, 1975, p. 331) but in trying to discover the true strength of what he is saying through testing and then to foreground this. The truth which emerges in this way is the logos underlying the conversation, and which, in the case of drama, transcends the subjective conceptions 


\section{P. C. Jansen van Rensburg}

of the play and the playgoer so far that it places them within the infinite horizon of life itself. The playgoer then ultimately ends not only with a perception of the message of the play, but in reality he touches on the mysteries of life itself. Message perception in drama, then, is more than perception of the message of the actual play in question - it is also a perception of the message of life through the medium of the drama (as discovered in the course of this conversation).

I would like to leave it at that for the moment. I trust that the few guidelines about the subject that I could touch upon will stimulate further thinking in this direction.

\section{SUGGESTED SOURCES FOR FURTHER READING}

DEWEY, J. 1934. Art as Experience. New York, Milton, Balch and Co.

GADAMER, H. G. 1975. Truth and method. London, Sheed and Ward.

GADAMER, H. G. 1976. Philosophical hermeneutics. Los Angeles, UP of California.

RADER, M. and JESSUP, B. 1976. Art and human values. Englewood Cliffs, PrenticeHall

ROOKMAKER, H. R. 1978. Art needs no justification. Leicester, Inter-Varsity.

SCHAEFFER, F. A. 1978. Art and the Bible: two essays. Downer's Grove, Inter-Varsity SEERVELD, C. L. 1968. A Christian critique of art and literature. Toronto, The Association for Reformed Scientific Studies.

SHANK, T. 1969. The art of dramatic art. Belmont, Dickenson.

WOLTERSTORFF, N. 1980. Art in action; toward a christian aesthetic. Grand Rapids, Eerdmans. 